ARTICLE

Received 29 Jun 2015 | Accepted 20 Aug 2015 | Published 13 Oct $2015 \quad$ DOl: 10.1057/palcomms.2015.28

\title{
A radical theology for the future: five theses
}

Jeffrey W Robbins ${ }^{1}$ and Clayton Crockett $^{2}$

\begin{abstract}
This article sketches out five theses of radical theology to contribute to a vision of the future of theology. Radical theology emerged out of the Death-of-God theology of the 1960s, as well as some forms of liberation theology. These theologies challenge the orthodoxy of most traditional forms of theological and religious reflection. Here the authors, who are part of the conversation of radical theology in the United States and elsewhere, sketch out five theses: that radical theology should be postsecular, postliberal, a version of political or liberation theology, an onto-theology and an eco-theology. Each of these terms, however, needs to be qualified with a difference that distinguishes them from more common understandings of these terms. Finally, we argue that radical theology should be materialist in a non-reductionist way that reconfigures but does not simply dismiss our ideas about God, humanity, religion and the world. This article is published as part of a thematic collection dedicated to radical theologies.
\end{abstract}

\footnotetext{
${ }^{1}$ Lebanon Valley College, Annville, USA (e-mail: Robbins@lvc.edu) 2 University of Central Arkansas, Conway, USA. Correspondence: (e-mail: ClaytonC@uca. edu)
} 


\section{Introduction}

$\mathrm{n}$ this article we offer five theses on the future of radical theology. Here we assume a theological method that is neither reformational nor conservative, but instead transformational and radical. The tradition of radical theology has had a recognizable lineage and sensibility that makes it an identifiable tradition of thought that can be invoked and whose limits can be pressed. We stand in a tradition of radical theology in the United States that began with Paul Tillich in the middle of the twentieth century and extended through the death-of-God theologians of the 1960s, including Gabriel Vahanian, Thomas JJ Altizer, William Hamilton, Harvey Cox and Richard Rubenstein. In the 1980s, the postmodern theology of Mark C Taylor, Carl A Raschke and Charles E Winquist conjoined the insights of the death-of-God theologians with the reception of French poststructuralism and deconstruction. Later in the 1990s and early 2000s, a Continental Philosophy of Religion formed around the work of John D Caputo that has affinities with radical theology, and in fact Caputo himself has come to affirm and embrace radical theology in this century, in his works The Weakness of God and The Insistence of God.

The first book in death-of-God theology was published by Gabriel Vahanian in 1957. In that same year the evangelist Billy Graham held a mission in New York City's Madison Square Garden, where he filled the arena every night from 15 May to 1 September. The mission was labelled the "New York Crusade", and over the course of its 16 weeks duration, over 2 million people attended. The success of the crusade solidified Graham's national profile as the voice of American evangelicalism.

Less than a decade later after the publication of Vahanian's The Death of God, TIME magazine published its famous cover story on the death-of-God movement. At the time, it was the bestselling issue in the magazine's history. Yet only 3 years later, the cover read, "Is God Coming Back to Life?" In a letter from the publisher, TIME editors wrote:

On April 8, 1966, TIME's cover posed the question "Is God Dead?" The story discussed the emergence and growing voice of the "God is dead" school of theologians. It proved to be one of the most provocative articles the magazine has ever run, and for months the arguments and addenda kept coming in from concerned readers.

Recently, the death-of-God theologians have fallen silent, while ministers of all denominations have embarked on new, dynamic ways of bringing the divine back into daily existence. Hence TIME's follow-up cover story, "Is God Coming Back to Life?". (TIME, 1969)

If the death-of-God theologians fell silent, Graham's notoriety only grew. He would become the spiritual advisor to a succession of US presidents for nearly 50 years beginning with Dwight Eisenhower and extending to George W Bush. At the same time, the born-again movement he represented went from the margins to the mainstream of American society and culture, and from being piously indifferent to politics to becoming a successful strategy for political mobilization.

By this parallel, it seems evident that radical death-of-God theology's time was short and its impact slight. The standard reading by scholars is that it was too academic and never truly reflective of people's sense of religiosity. While the death-of-God theologians were garnering the headlines, evangelicalism was building itself as a movement that included both a distinct ecclesiology and politics. And because radical theology never established itself in any institutional form beyond that of academia - and even there, more as solitary voices functioning as agent provocateur-its ability to carry forward its legacy has been mitigated. It is not that the original death-of-God theologians stopped teaching and writing, but increasingly their movement has come to be regarded as a flash-in-the-pan, a framed vainglory in which the post-Christian man announced a world come-of-age after the death-of-God only to witness not simply the return of religion, but the growth of fundamentalisms, the success of evangelical electioneering and a violent clash of civilizations along religious identitarian lines.

We do not subscribe to this standard narrative. Not only is radical theology alive with an identifiable lineage and as a discernible tradition of thought, but it never died in the first place. The mistake is to read radical theology exclusively in terms of the death-of-God movement. More broadly, radical theology is a postliberal tradition of thought that emerges out of the death-ofGod movement of the 1960s. But while it emerged out of the death-of-God movement, radical theology is not bound by it. A radical theology that recognizes its complicity with the deathof-God but is unbound from it as a historical phenomenon has a future, and this future can be summarized in the following five theses.

\section{Five theses}

Radical theology is postsecular, with a difference. Within the broad field of religious studies, there has been a reconsideration of the basic secularist assumption that has been operative throughout much of the history of the academic study of religion -namely, the notion that the more modern we become, the less religious we would become. The so-called "secularization thesis" was brought into serious question by scholars of religion long before the events of September 11. However, after September 11 these academic discussions became part of a much larger, and more public dialogue, making some, such as the American conservative political columnist David Brooks, to describe themselves as "recovering secularists". As Brooks (2003) writes in a column for The Atlantic Monthly in March 2003, the secularization thesis has proven to be "yesterday's incorrect vision of the future".

This secularist assumption is a residue of the ambiguous legacy of the Enlightenment. The historian of religion Smith (1982: 104) claims that "the academic study of religion is a child of the enlightenment". As the product of the enlightenment the very concept of religion harbours up not only an intellectual tradition that has domesticated religion by delimiting religion within the sphere of secular reason alone, but also one that has passed down its attitude of scepticism, if not outright hostility, towards faith as a lesser form of knowledge and religion as exclusively either a matter of superstition or dogma.

Correlatively, the anthropologist of religion Talal Asad, who is equally interested in the construction of religion as an academic category, has shown how in conjunction with the enlightenment rationalist project outlined by Smith there are the political consequences of the colonial subjugation by the West of other cultures and religions. For Asad, the political promise held out by the West for emancipation carries with it the religio-cultural significance of normalizing secularization as the proper mode by which religion ought to be practiced, meaning the liberal strategy of containment wherein religion is treated exclusively as a private matter of individual conscience. When applied to the academic study of religion this has all too often resulted in an undue priority being placed on belief over ritual and a treatment of religion as an "essentially cognitive" matter made up of a "set of propositions". This reduction of religion to individual belief not only shows how religion has become increasingly marginalized in the modern world, but also betrays the covert theological bias that continues to exist within the field of the study of 
religion-namely, that the academic treatment of religious belief "is a modern, privatized Christian one" (Asad, 1993: 47). As Asad (1993: 45) writes, "This modest view of religion (which would have horrified the early Christian Fathers or medieval churchmen) is a product of the only legitimate space allowed to Christianity by post-Enlightenment society, the right to individual belief".

It is true, as Asad and others such as Jacques Derrida and Jonathan Z Smith have pointed out, that the terms "religion" and "secular" are not "translatable", that they have a Latin root and they carry with them a history in which they have been forcibly imposed. This becomes most apparent when we consider the assumptions made about the connection-or lack of connection-between religion and politics. For Asad, behind the Western mandate of the separation of Church and State rests a twin assumption that on the one hand associates modernization with secularization and on the other treats religion as an exclusively private, individual affair of personal conscience. As he writes, "This is at once part of a strategy (for secular liberals) of the confinement, and (for liberal Christians) of the defense, of religion", and further that "this separation of religion from power is a modern Western norm, the product of a unique post-Reformation history. The attempt to understand Muslim traditions [for instance] by insisting that in them religion and politics are coupled must, in my view, lead to failure" (Asad, 1993: 28).

Meanwhile, it has become increasingly apparent to many that the private is not without public consequence and that in spite of the efforts at separating religion from politics the religious is always already a political affair. This is the subject of Derrida's essay on religion entitled "Faith and Knowledge: Two Sources of 'Religion' at the Limits of Reason Alone", which is often times credited with bringing the current global resurgence of religion to the attention of philosophers. With this current interest in the political dimension of religion and with studies supporting a certain resurgence of religion on an individual level and the public visibility of religion within the political realm, it is clear now, as Berger (1999: 18) once cautioned, that "Those who neglect religion in their analyses of contemporary affairs do so at great peril". Berger, who was a one-time advocate of the secularization thesis, notes that we have moved from a secular age to a postsecular world wherein it can no longer be safely assumed that the public is best served by keeping religion private.

It is ultimately Gianni Vattimo, however, who is most helpful in showing the way by which radical theology is a postsecular theology. For Vattimo, secularization is a process of desacralization that establishes the contemporary cultural conditions through which today's religions might have meaning. This is in accordance with his reading of the history of philosophy as the weakening of being. In this sense, the postmodern return of religion is very much a postsecular religiosity by virtue of the fact that there is no longer a unified religious authority-in short, religious authority has been relativized. But while Vattimo has frequently explored the significance of this so-called return of religion, he is careful not to confuse it with what others have called "desecularization". For instance, when asked whether the return of religion disproves the secularization thesis, Vattimo (2007: 98) answers frankly, "I don't know what a desecularized world would be". That is because, as he expressed earlier in that same conversation, whatever the nature of this resurgence of religion, it is "a religiosity that lives only as a consequence of secularization”.

In this way, we can say with Vattimo that the postsecular is not a repudiation or reversal of secularization, but is its historical and cultural consequence that requires us to take note of the enduring existence of the religious. In the words of Hans Joas, "Postsecular' ... doesn't express a sudden increase in religiosity, after its epochal decrease, but rather a change in mindset of those who, previously, felt justified in considering religions to be moribund" (de Vries and Sullivan, 2006: 2-3). Along with this, however, comes a changed public perception about religion together with a revised politics about the proper role of religion within the public sphere. This is an argument put forward by de Vries when he associates the postsecular with the opportunity to rethink the role of religion within the public sphere or the proper relation between religion and politics, and between the private and the public. As de Vries writes, "In such a reading, what undergoes transformation is less the nature of the secular state, let alone its constitutional arrangements guaranteeing, say, a separation between church and state, but rather the state's 'secularist selfunderstanding'" (de Vries and Sullivan, 2006: 3).

In summary then, those for whom secularization meant a diminishment of religious belief or the fading away of religion from the public's consciousness, clearly David Brooks' quip is correct: that was yesterday's incorrect vision of the future. But for others for whom secularization refers to the altered epistemological, cultural and political terrain in which religion is practiced, believed and studied, even in the midst of today's postsecular world, these remain live questions that must be pursued. Therefore, when we posit that radical theology is postsecular, this should not be construed as a theology of secularism. That is to say, it does not forecast the demise or insignificance of religion. Likewise, its aim is not to dismantle old beliefs and to advocate unbelief as the enlightened option. On the contrary, much more in line with how Strenski (2006) conceives the scholar of religion who "thinks religion" neither as an attacker nor a defender of religion, but rather as a critic, the radical theologian may think theologically but non-dogmatically.

At the same time, a radical theology, which is situated in a pluralistic society with a diversity of beliefs, is not beholden to the secularization thesis. The term secular indicates its autonomy from religious control and the recognition that even though not speaking in an official capacity on behalf of the positive religions or the historical faith communities, there is still the need to reflect on the meaning of a society's sense of ultimacy. It is secular in the sense that it is worldly.

If the saeculum is the shared world that provides the common ground upon which distinctions between the sacred and the profane are made, then by its effect of desacralizing a radical theology is also an act of profanation. This is like what Sam Gill says of the impact Jonathan Z Smith has had on shaping the field of religious studies. As Gill (1998: 306) writes, "Smith's approach can only be recognized as an act of profanation".

As historians of religion have acknowledged their outsider status, so too does radical theology accept its outsider status. Whereas the history of religions removes the sacred from the temple, radical theology is removed from the church. Indeed, radical theology faces a double exile. Not only is it a re-placed theology that has been displaced from its original home within an ecclesiastical context in service to the church, but it also defines itself as a non-dogmatic practice. This means that it purposely does not advance a particular confessional perspective and it is independent of, and not answerable to, religious authority. Nevertheless, there remains a certain suspicion, if not hostility, to the very idea of doing or even studying theology within an academic context. For instance, countless genealogies of the academic field of religious studies have suggested that the making of religious studies as a legitimate and respectable member of the academy requires it to purge it of its theological residue (see Capps, 1995). In this way, in a state of double exile, radical theology is simultaneously a profanation of ecclesiastical, confessional theologies and a profanation of religious studies as it is currently constituted. 
In sum, to say that radical theology is postsecular is to acknowledge the secularizing effect on what it means to think theologically - that is to say, the ways by which theology has been desacralized and profaned. As we have learned from Feuerbach, theology is in and of the world. And as we must still learn, theology must be made for the world. In this way, radical theology takes its lead from Tillich's theology of culture. But unlike Tillich who transforms the formal nature of theology while keeping its essential truths intact, for a radical theology both the means and content of theological thinking are fundamentally altered, or at least put into question (see Manning, 2015).

Radical theology is postliberal, with a difference. Radical theology is postliberal in a way, but the difference here must be specified in two different registers. First, by postliberal we do not mean to conjoin radical theology with the postliberal, neoBarthian school of theology associated with Hans Frei, George Lindbeck, Stanley Hauerwas and others. Radical theology is neither neo-traditional nor confessional. Indeed, this is the main point of differentiation for John D Caputo's radical theology in The Insistence of God, which we endorse. Caputo distinguishes between confessional theology and a circumfessional theology, the former of which actually exists as the concrete expression of existing religious communities, and the latter of which insists as a demand of thought responsive to the event harboured within the name of God. As Caputo (2013: 60) explains, "I start with confessional theology while trying to expose it, to expose myself, to its own excess, to hold us all open to the event". As such, it is a theology under erasure, or as it is otherwise known, a "weak theology".

Second, by postliberal we do not mean a repudiation of liberal theology; instead, we want to mark a particular lineage of thought that grows out of the liberal tradition but nevertheless can and should be distinguished from it. Radical theology's history is a relatively brief one, beginning in the post-World War II years in a time of considerable angst and upheaval. Essentially simultaneous with the Non-Aligned Movement committed to the political task of decolonization that functioned as an external dismantling of Western hegemony, death-of-God theology developed as an internal movement within the West functioning as an immanent critique. For some, this was equivalent to a post-Christian era as the moral-metaphysical God of the West had been revealed as a false idol bequeathing a legacy of xenophobia, misogyny and genocidal violence. For others, the death-of-God was taken less as a cultural moment in time and more as a metaphysical truth and thereby announced as the "Gospel of Christian Atheism", to paraphrase Thomas JJ Altizer's more famous title.

In a more basic sense, radical theology was born with Dietrich Bonhoeffer's prison cell writings wherein he issued the challenge to live in a world without the working hypothesis of God. This is the world come-of-age and represents a distinctly postliberal sensibility in that like Barth before him, Bonhoeffer totally repudiated the cultural form of religion that was great achievement of the likes of Kant, Hegel and Schleiermacher in their efforts to salvage religion from the Enlightenment critiques. Bonhoeffer's call for a religion-less Christianity set the template for radical theology's self-distancing from religion. From this perspective, it is easy to see the continuity between Bonhoeffer and Caputo, whose reading of Derrida's "religion without religion" represents just a variation on a theme.

To draw the contrast between modern liberal theology and radical theology more clearly, a brief introduction to liberal theology is first in order. For this, we turn to the work of the intellectual historian and ethicist Gary Dorrien whose threevolume work, The Making of American Liberal Theology, is the authoritative and exhaustive text that makes the case for how "liberal theology has been and remains the most creative and influential traditional of theological reflection since the Reformation" (Dorrien, 2001: xv). As Dorrien tells it, liberal theology is a three centuries old tradition. It is defined by its openness to "modern intellectual inquiry" and "the authority of individual reason and experience", its understanding of Christianity "as an ethical way of life", and its "commitment to make Christianity credible and socially relevant to modern people" (Dorrien, 2001: xviii). What has given liberal theology its critical edge as a modernizing, progressive and democratic force, has been its effort at doing theology without being based on external authority, whether this religious authoritarianism comes in the form of tradition, the appeal to clerical or institutional authority, or the notion of the infallibility of scripture. And finally, Dorrien (2006: 1) makes frequent reference to the "mediationist character" of liberal theology, locating it as the "third way between conservative orthodoxy and secular disbelief". In this way, liberal theology is self-consciously and consistently reformist in its intentions and sensibility, and not revolutionary.

Like the tradition of liberal theology, radical theology is also characterized by its openness to contemporary ways of knowing and critical modes of enquiry. Like liberal theology, radical theology rejects arguments from authority. But it takes this further, which might best be explained by its more recent beginnings. Whereas Dorrien dates the beginning of liberal theology to 1805 , radical theology traces its beginnings to the death-of-God theologies of the late 1950s and 1960s in a cultural moment identified in the first book-length study of the death-ofGod as "our post-Christian era" (see Vahanian, 1957). So whereas liberal theology arose first in Germany as a creative intellectual response by the likes of Kant, Hegel and Schleiermacher in the attempt to reconcile with-if not salvage Christianity from-the ravages of the Enlightenment rationalist critique of religion, radical theology is post-Christian insofar as it comes "after Auschwitz" in what one author describes as "the twilight of the American Enlightenment" (see Rubenstein, 1966; Marsden, 2014). It acknowledges the loss of hegemony and moral authority suffered by Western Christian culture. As such, it helps to announce the end of the liberal Protestant establishment. In this way, radical theology stands to liberal theology as its historical bookend, more liberal than its theological precursor of neoorthodoxy and in many ways it has been less political than its theological successor of liberation theology.

Finally, by the term liberal we are less concerned here with the tradition of liberal theology per se than with modern liberalism writ large. It is on this point where the work of legal theorist Paul Kahn is instructive. In his book applying Carl Schmitt's political philosophy to the United States, Kahn argues that strictly speaking there is no liberal concept of the political: "political theology, unsurprisingly, has no place in the liberal conception of the state", which instead works "to expand the horizon within which we understand the operation of the political imagination" (Kahn, 2011: 25). Kahn uses political theology to show how the concept of sacrifice lies at the heart of the American political imaginary.

Liberalism assumes that politics is pure procedure, a mechanism that leaves the deep problems of the political to one side. For us, postsecularism and postmodernism constitute a postliberalism that is not thereby antiliberal because it does not side with conservatism. Liberalism, like secularism, is a modern ideology that must be interrogated without simply assuming that the liberal and the secular disappear.

Modern liberalism assumes a split between public and private spheres that is breaking down. In A Letter on Toleration, Locke (1968: 65) argues that "I regard it as necessary above all to 
distinguish between the business of civil government and that of religion, and to mark the true bounds between the church and the commonwealth". The business of government is the state whereas the business of religion is the church. The church, moreover, is the private sphere of voluntary association and activity within the context of a liberal state. In secularism, religion takes the form of private belief, sundered from public political activity.

What is sometimes called the "return of religion" is more correctly what Casanova (1994) calls a "deprivatization" of religion, or the increasing difficulty of holding onto this separation between public and private religion. Another way to put this is to say that the strict opposition between public and private religion, as well as the opposition between the religious and the secular, is untenable-it deconstructs. Just as with the postsecular, we need to think beyond secularism and beyond liberalism. It is in this way that we want to think what radical theology has heretofore left unthought about the political. Liberalism today has been sundered into a largely emotional appellation-to be a liberal is to care about social programmes and people who are less fortunate, often from a position of privilege-and a brutal economic form of neo-liberalism. Radical theology seeks tools to expose and oppose contemporary neoliberalism.

Our critique of actually existing radical theology-or better, at effort at pushing against its limits-has not been that it has somehow been complicit with regimes of power, this in spite of the fact that it has operated almost entirely within the provenance of a largely Western and Christian discourse and that it has largely neglected the potential alliances between feminist, liberationist and process thinkers. Instead, our critique is that it has been ineffectual. This critique is consistent with the standard academic narrative of the movement, but with a difference.

There is little debate over the fact that radical theology has been marginalized and obscured. But what we want suggest is that it is possible to make a virtue out of this necessity. This is the importance of the rhetorical strategy adopted by Charles $\mathrm{E}$ Winquist when he identifies theology as a minor intensive use of a major discourse. Pushing Winquist even further, this rhetorical strategy must be identified as a point of resistance. This is not a form of play for personal edification, not the soteriological drama in another register, but a political act of creative destruction. It is postliberal in that it rejects the modern liberal separation of powers that renders religion merely as a cultural artifact or a matter of individual personal conscience. In short, radical theology is postliberal insofar as it is a political theology.

Radical theology is a political theology, or a liberation theology, with a difference. The problem with radical theology is that it has been insufficiently political and, further, that there has not yet developed a truly radical political theology. This concern has been mitigated in recent years both by those who self-identify with the radical theological lineage and by the widespread theoretical attention to political theology generally and to the legacy of Carl Schmitt more particularly (Robbins, 2011; Crockett, 2011).

But the more effective and far-ranging theo-political intervention has been that of liberation theology. And it has been certain feminist theologians and queer theorists who have best worked at the crossroads of radical theology and liberation theology. While the lineage of radical theologians we have invoked have largely neglected liberationist thought, pioneering figures such as Mary Daly and Rosemary Radford Ruether have long drank from both wells. Consider especially Ruether's (1970) work from 1970, The Radical Kingdom, in which she affirms and unleashes the revolutionary ideology that runs from the Radical Reformation through the death-of-God, civil rights, Black Power and anarchist movements of the twentieth century. Make no mistake, by her probing critique of all forms of hierarchy, patriarchy and violence, this is a feminist theology that is a radical theology. And even more, this radical feminist theology demonstrates not only the possibility, but also the efficacy of a radical political theology.

Likewise with the work of Marcella Althaus-Reid, she has acknowledged the roots of liberation theology as a dynamic theology that once embraced the hermeneutics of suspicion. But when it comes to issues of sexuality and family norms, she charges it has been seized by a kind of orthodoxy. Interestingly, this heterosexual norm is not a reflection of the views or priorities of the base ecclesial communities, the urban poor and those who have been excluded from Church discourses for centuries, but instead a product of academic colonization on the part of EuroAmerican scholars. Althaus-Reid (2006: 2) claims a that a "kind of closet Liberation Theology developed at the fringes of the churches that has been closer to popular Latin American spirituality and culture than the orthodox liberationist discourses". This closet theology is a radical theology of kenosis-so radical, in fact, that it is not only emptied of "ideological methodologies", and its message is not only fundamentally altered, but it also runs the risk of its own death (Althaus-Reid, 2004: 72). What Althaus-Reid shows is a liberation theology that puts (its own) difference at the centre of its critique and renewal. As such, it is a liberation theology with a difference.

Radical theology is about changing difference. And here we want to bring together Althaus-Reid with the philosophy of Catherine Malabou, who is a philosopher of plasticity and change. As the editors of a recent collection on Malabou's work assert, "Malabou seeks to philosophically recover form by grasping it as always already in restless motion. She is foremost a philosopher of change" (Bhandar and Goldberg-Hiller, 2015: 3). It is Malabou's concept of plasticity that provides us with the material basis for our effort in developing a radical political theology. Specifically, she breaks down the dualisms not only between mind and brain, but also between form and matter, culture and nature, and ideality and materiality. Thinking effects change insofar as thinking is a material practice through and through. In her book The Heidegger Change, Malabou ignores the standard interpretations of Martin Heidegger's philosophy and reads him in a fresh and compelling way. She focuses on three German terms: Wandel (change), Wandlung (transformation) and Verwandlung (metamorphosis), and traces their persistence through much of his work. Malabou (2011b: 2) claims that "the triad $W, W, \& V$ would then be what confers on Heidegger's thought its power and vigor, and what at the same time makes it good for something and fit for something else, an energy greatly needed in the world of today". Malabou reads these three terms as a way to understand change in Heidegger's philosophy, but more importantly as a way to change it.

The three terms for change- $W, W \& V$-constitute an exchange, and exchange where Heidegger's entire philosophy changes from what it is to what it can become for us, which is what makes it fantastic. This triad of change is for Malabou a way to rethink the ontological difference, Heidegger's celebrated difference between Being (itself) and (particular, determinate) beings. What is the nature of being? Change. Being changes, it transforms and metamorphosizes itself, both the Being of being and the beings that transform themselves. Change is the transformation of form, or what she calls in What Should We Do With Our Brain? the trans-differentiation of form. According to Malabou (2011b: 21), "Heidegger characterizes metaphysics as a 'form' that changes from epoch to epoch by being re-formed, even as he just as much promises 'the other thinking' to be transformation in the literal sense-a passage or transition to another form". 
If we are masochistic enough to read and think about Heideggerian Being, we usually assume that the Being of beings does not change, even if beings do. But the good news here is that "the good old beings of metaphysics are no more". Malabou (2011b: 157) says that "there is an exchange between being and beings that is not an incarceration of the ontological difference, but its liberation". This liberation concerns change as the transformation of form, the exchange of Being and being in a seemingly impossible exchange that is radical, real and revolutionary.

Malabou reads an economics of exchange at the heart of Heidegger's thought. She claims that "a proximity between Heidegger and Marx indeed exists, and it doubtlessly lies in the possibility of the ontological and economic coinciding within the definition of exchange, of exchange and mutability, of the metamorphosible and displaceable character of value, and of the impossibility of transgressing all this plasticity" (Malabou, 2011b: 277). In this context that is both economic and ontological at the same time, every modification of Dasein (the there of Being, or the being who asks the question of Being) is intrinsically revolutionary. She says that the genius of Heidegger consists "in having inscribed the possibility of revolution not in a future event to come but in the fact (so modest, slight, and tiny) of being-there, of still being there after the accomplishment that was never accomplished" (Malabou, 2011b: 278). Every slight change is the manifestation of transgressive power, because it affects the being of change itself, form, which is the change of Being itself.

Being is plastic, because it changes form. It is also metamorphic, it changes Being itself, because Being itself is change, or exchange. There is an exchange of being that transforms existence in every being-there, every Dasein. "Existence itself surpasses metaphysics", writes Malabou, and "we started a revolution without at all realizing we were" (Malabou, 2011b: 279). In What Should We Do with Our Brain?, Malabou (2008: 68) says that our brains are telling us to resist the flexibility that is prescribed by the ideology of neo-liberal capitalism: "What we are lacking is life, which is to say: resistance. Resistance is what we want". In a new materialism there is no dualism between brain and body. Our bodies are telling us to resist, revolt, insurrectchange. Change the difference that we are. Stasis is not the idea of nature; "energetic explosion is the idea of nature", including the auto-destruction of form, which is the lesson of destructive plasticity (Malabou, 2008: 73). Malabou says that life is about resistance and resilience, not flexibility, because change is not adaptation to this or that condition of global capitalism, it is the ability to change conditions, to blow up. If we are too flexible, "if we didn't explode at each transition, if we didn't destroy ourselves a bit, we could not live. Identity resists its own occurrence to the very extent that it forms it" (Malabou, 2008: 74). The formation of identity is not simply the play of differences, but the resistance of plasticity that creates it. Identity and difference are grounded in change. And radical theology is focused on the change that changes difference.

In her book Changing Difference: The Feminine and the Question of Philosophy, Malabou directly reflects on complex issues of gender and sexuality from the standpoint of her identity as a woman philosopher and her viewpoint of plasticity. She argues that "to construct one's identity is a process that can only be a development of an original biological malleability, a first transformability. If sex were not plastic, there would be no gender" (Malabou, 2011a: 138). In an essay on "The Meaning of the 'Feminine'", Malabou develops her own thought in relation to that of Luce Irigaray and Judith Butler. Here Malabou complicates the already complicated relationship between the feminine and woman. She says that the terms of this relation need to be displaced, and she refers to her analysis of the exchange between Being and beings in her book The Heidegger Change. "Being and being change from one into the other", she writes, "that's the plasticity of difference" (Malabou, 2011a: 36). Beinghere the feminine, and beings-in this case women-"exchange modes of being". This substitutability exceeds metaphysics, because both Being and beings change in their exchange. If "substitutability is the meaning of Being", then "transvestitism comes with difference" (Malabou, 2011a: 37). Being is not incarnated in embodied beings, but bodies manifest Being as change even as they change Being by exchanging it.

Malabou opens up the question of the feminine to the transformation of Being, and the change in difference that female beings make. This is a kind of transvestitism because the woman does not remain unchanged. She refers to a point in her Heidegger book where she and her translator, Peter Skafish, decided that the word essence in Heidegger's philosophy is a kind of "going-in-drag" (Malabou, 2011a: 39). If gender is a genos, a genre or an essence, and essence is always going-in-drag, then that suggests a kind of transvestitism of Being and beings, a clothing across the heart of existence. Malabou (2011a: 39-40) concludes that "while the feminine or woman (we can use the terms interchangeably now), remains one of the unavoidable modes of ontological change, they themselves become passing, metabolic points of identity, which like others show the passing at the heart of gender". Tracing the feminine leads us to a passing that is inscribed at the heart of gender, which is a different difference than that of stereotypical postmodernism.

Likewise, it is a different difference than that which has animated the politics of identity, and also different from AlthausReid's indecent theology. This puts the moral, political, theological and philosophical critiques of essence into critical relief. When employed in discussions of sexuality and gender or with race, the problem with talk of essence is that it implies, is associated with and is employed towards the end of a fixed essence, a naturalization of social norms, an ideological construction that then provides the rationalization of, and script for, continuing prejudice and oppression. But what if, in contrast to this fixed view, essence is thought of in plastic terms as a "going-in-drag"? The differences would be no less real-even no less material or biological-even while being recognized as a product of our own making. Difference has a history, a heritage even. Differences matter. And while these differences are real, biological and material, that need not imply that we are stuck in or with these differences, captive to this history, a perpetuation of the same. Because just as change comes before difference, change never stops-without beginning or end, a metabolic ontology that just might be the basis of a new and different liberationist thinking.

This is the radical political theology at which we aim. Its merit would be a more robust political ontology. This would be a political becoming of radical theology that does not eschew ontology for its tendency at totalizing or essentializing, but instead recognizes in being the very nature of change and resistance. As such, it would be a revolution for both radical theology and liberation theology alike.

Radical theology is onto-theological, with a difference. At least since his short instructional text, Philosophy and Theology, Caputo has sought to bring philosophy and theology together. He advises thinking the two as "different acts or modes of thinking, as two different dimensions of a whole human life" that can happily and productively coexist. By holding the two together, it yields thinking believers, or believing thinkers, people "of learning and of faith" (Caputo, 2006: 6). In Continental philosophical and theological terms, at least since the time of Heidegger and his 
highly influential critique of the so-called problem of ontotheology, this mixing of discourses has been more the exception than the rule. For the most part, philosophers and theologians following in the wake of Heidegger have wittingly or unwittingly accepted his prescriptive analysis that philosophy and theology make two, along with the consequent assertion that there can be no Christian philosophy or philosophical theology, or that to write a theology, the word being should not appear.

And so, returning to Caputo, he identifies two types of postmodern philosophy of religion, one that takes its lead from Kant and the other from Hegel. For the former, religion is conceived as the unthought and the unthinkable, factually unknown and structurally unknowable. Kant salvages religion from the modern Enlightenment critique of it as dogmatic, superstitious and irrational, but at a high price-namely, he cuts faith off from reason, and thus separates theology from philosophy. At the same time, Kant reduces religion to morality, the only manifestation of religious life that safely abides within the confines of reason alone. Hegel, on the other hand, thinks the two together. In Caputo's (2013: 90) words, “The truth needs philosophy but philosophy needs religion". Rather than locating faith outside the bounds of reason and correlatively reducing religion to morality, religion is seen as a Vorstellung, or a figurative presentation of truth found, for instance, in the Christian stories of the incarnation, crucifixion and resurrection of Christ. This is the prerational stuff of religious life that nourishes theological thinking. It is for this reason that Caputo credits Hegel with effectively inventing radical theology. Hegel has moved beyond the rationalism of Kant's delimitation of religion within the limits of reason, and at the same time has rejected the otherworldliness, "mythic supernaturalism" or "twoworlds dualism" of classical orthodoxy. As Caputo (2013: 90) writes, "Hegel has undermined the subordination of reason to revelation, of philosophy to revealed theology, and in the process made the contents of revelation part of the business of philosophy".

We do not want to diminish the significance of this breaching of the divide between philosophy and theology. This insistence on treating philosophy and theology as two separate and distinct discourses has been one of the most unfortunate consequences of the identification and analysis of the problem of onto-theology. But it gets us only part way to the more fundamental task, which is the rethinking of the onto-theological condition itself (see Robbins, 2003). While much of contemporary philosophical theology has been preoccupied, if not consumed, by the task of overcoming onto-theology, theology might become more radical by thinking onto-theology otherwise, by embracing rather than resisting the onto-theological dimension of thought. This is where Malabou's work figures in. In short, beyond radical theology's almost exclusive identification with the death-of-God comes Malabou's profession: God is not dead, but plastic.

The problem of onto-theology belies a quest for purity. In the place of this we can suggest miscegenation and metamorphosis as two images of what Goh (2014) calls the reject that might help to reclaim the onto-theological condition of thought. Onto-theology is a mixed discourse. It recognizes the ethico-political significance of thinking on the border. Thinking ontotheologically is a rejected way of thinking that nevertheless gives birth not so much to something new, as to something old, something impure. A miscegenated form of thought does not reject the reject, but instead it rejects the misguided quest for purity in the task of overcoming.

Likewise with metamorphosis, the traditional reading of the problem of onto-theology is concerned with how it establishes an artificial limit-from the beginning to end, and from the ground up, the identification of God with being is complete, a totalizing gesture that renders human history as irrelevant, if not dead on arrival. God is established as the eternal norm from which there can be no deviation. As such, onto-theology is the ultimate alienation: liberation is predicated on an impossible infinitude, (because) change is considered a violation of the natural order. And it is a fundamental self-contradiction: radical immanence betrays a secret desire for transcendence, (because) the being of God is a God beyond being. But what if, as Malabou insists, there can be "radical transformation without exoticism?" (Malabou, 2010: 44). If God is plastic then not only is God change, but God makes change and God changes. So given, the cause for concern that identifies onto-theology as a problem is eliminated. Metamorphosis does not represent the absurdist tragedy suggested by Kafka, but is instead the secret agent by which we might come to know better the nature of reality, the immanent possibility for change and the power of resistance.

By embracing the onto-theological condition of thoughtwhich in this case means accepting miscegenation and metamorphosis as appropriate figures of theological thought-radical theology might get beyond questions of identity (and difference), or the territorial disputes so endemic to the academic industrial complex. Purity emits the stench of otherworldliness. It is also haunted by the spectre of God as the graven image of white male normativity. This is the stillborn, moral-metaphysical God who is dead. Exposing the idolatry inherent in this form of ontotheology has been the critical task of radical, death-of-God theology heretofore.

Our onto-theology is a new materialist ontology of change. At its most fundamental level, being is energy transformation. The New Materialism is a non-reductionist materialism informed by chaos and complexity theory and the philosophy of Gilles Deleuze, including thinkers such as Rosi Braidotti, Manuel Delanda, Isabelle Stengers, William E Connolly and Jane Bennett. Other philosophical resources include Alfred North Whitehead and Maurice Merleau-Ponty. The New Materialism traces the processes of bifurcation, self-organization and emergence across thresholds rather than reduces beings to their smallest building blocks, whether they be atoms, quarks or strings. As radical theologians, we are committed to a material reality that does not exclude spirituality-there is no dualism between spirit and matter. Existence takes place within the context of what Deleuze calls a "plane of immanence", which is the consistency according to which things and events occur and make sense. Immanence means the refusal of appeals to transcendent realms and explanations, external appeals to an elsewhere. This insistence on immanence does not deny the experiential quality of transcendence, only the ability of appeals to transcendence to trump where we live here and now together in our world, which as Wittgenstein says is all that is the case.

Beings are metabolic, metastable entities who process energy. Living and non-living systems cannot persist without energy flow. Life is not simply genetic code, but requires the appropriation of solar and carbon forms of energy for work. Entropy is the second law of thermodynamics, which means that in every actual system, usable energy is lost. In a closed system, the entropy law means that systems tend towards homoeostasis, which is the achievement of equilibrium. However, the universe is not a closed system. We do not know where energy comes from, although the first law of thermodynamics posits that it is infinite, as it is always conserved. Dark energy makes up more than three-quarters of the stuff of the universe, and we do not really know what that is.

Non-equilibrium thermodynamics, as developed during the twentieth century, means that entropy needs to be reconsidered as the reduction of gradient differentials. A gradient such as temperature or pressure is simply a difference across a distance. Eric D Schneider and Dorion Sagan re-conceptualize entropy as 
gradient reduction in their book Into the Cool. They argue that "nature abhors a gradient", and works to reduce it as efficiently as possible (Schneider and Sagan, 2006: 6). Life is what Ilya Prigogine calls a dissipative system, which means that it is an open system fuelled by the continual flow of energy. These systems are non-equilibrium systems. Schneider and Sagan (2006: 7) claim that "life's emergence and evolution is... a cyclical process sired by energy flow".

Life is an open, non-equilibrium system with a difference, the stability of cells and cellular genetic and epigenetic systems that allow energy flow to become metastable, patterned and structured. Our ontological condition is an energetic situation governed by thermodynamic constraints that opens up complex opportunities and possibilities for transformation. Our theological demand is to be responsive to this condition.

Radical theology is eco-theological, with a difference. Human beings are earth-beings, because Earth is the only planet we know of that supports and sustains life. Over the past few decades we have discovered how closely humans are connected to other animals, plants, bacteria and eco-systems, even as we are increasingly aware on how threatening human activity has been to the stability of the environment and the climate. Many ecologists and naturalists claim that we live in a new geological era, the Anthropocene Era, a name coined by Eugene Stoermer in the 1980 s to indicate the fact that our world is completely different due to our own actions and their effect on the planet. Ecology becomes crucial as we recognize that we live in an era of radical transformation that has resulted in an acute state of crisis in our relationship with the earth. The swelling of human population, the spread of human civilization, and the stripping of animal and mineral resources are creating a precarious situation of environmental crisis. This is not simply an effect of humanity on nature, but an effect of humanity on humanity, because human beings do not and cannot exist without an environment. Without nature, there is no humanity, even if some philosophers like Tim Morton and Bruno Latour call for an end to the use of term nature to name a separate realm from human activity.

Human beings are the only beings we know of that engage in theological reflection. But that acknowledgement should not force us to embrace a suspect anthropocentrism. A radical theological thinking must be a radical ecological thinking, because the ecological horizon is more and more insistent on everything humans do and think. According to Lovelock (2009: 13), who coined the Gaia hypothesis, "the evidence that the Earth behaves like a living system is strong". There is a sense in which the planet becomes sentient through its inhabitants, including humans. Overall, the organisms and systems share complex interrelationships and feedback and feedforward loops.

For many years, Lovelock argues that the resilience of the earth's systems would ward off large-scale climate change due to global greenhouse emissions, but in this century he has changed his mind. Lovelock claims that many of the climate models, including the IPCC (Intergovernmental Panel on Climate Change), use their own models and presumptions rather than actual real inputs. Lovelock argues that according to his interpretation, there is a good chance that the global climate will shift very rapidly to an average temperature approximately $5^{\circ} \mathrm{C}$ higher around the middle of this century. The reason for the abrupt jump is due to the non-linearity of the systems involved (Lovelock, 2009: 53). If Lovelock is correct, and even if he is not, human civilization faces enormous challenges over the next few decades, because large-scale climate change is happening all around us, even as corporations desperately attempt to cast doubt on its existence.
Any theology of the twenty-first century will be an ecological theology, or a generalized theological ecology. Our radical theology is thus eco-theological, but with a difference from standard versions of eco-theology insofar as we dispense with the idea of any pregiven nature. Contemporary eco-theology draws on resources in the Jewish and Christian traditions, as well as other religious traditions, including pagan orientations, that offer more affirmative views of nature and the natural world. These traditions, resources and formulations are sophisticated, but many boil down to a similar critique. Although Christianity and the West have done great harm to the natural world by treating it as a resource to be exploited-and this fundamental attitude is related to the treatment of non-human animals, women and nonWestern colonial others-nevertheless, if we can liberate the true essence of Christianity, sometimes purged of its Greek overlay, we can restore harmony between men and men, men and women, and man and nature. Christianity is here what Plato calls a pharmakon, a gift that is both the poison of the world and potentially its cure.

For an example, we can consider the book Finding God in the Singing River, by Mark I Wallace. Wallace claims that "God is carnal, God is earthen, God is flesh", precisely because God takes human form in the incarnation, and the Holy Spirit then repeats this move, incarnating itself in the world. The spirit as the third person of the divine Trinity "has been persistently infusing the natural world with divine presence" (Wallace, 2005: 23). The incarnation of God in Jesus and the descent and continuing presence of the Holy Spirit affirms the presence of the divine in and to some extent as the world. Wallace and other eco-theologians extend the incarnational Christ beyond Jesus to include other humans as well as the natural world as a whole. He claims that "it is theologically proper to say, therefore, that the world is the 'form' God takes among us, that the earth is the 'body' of the Spirit we encounter daily" (Wallace, 2005: 23). If God takes form as earth, then the violence that humans do to the earth, as well as each other, is a violation of God.

According to Wallace, God gives up godself to our will, our technology, our domination and brutalization, and this is also kind of crucifixion. He calls it a "cruciform spirit", because, "if God's body ... continues to suffer and bleed, then does not God, in some sense real but still unknowable and mysterious to us, also suffer and bleed?" (Wallace, 2005: 23). We live in a sacrificial world, where the death of one form of life sustains the live of another, in a web of life that is based on death understood in exchangeable and sacrificial terms. Traditional religious transcendence tends to place humanity outside of this sacrificial order, along with God, and excepts human beings from this process. Eco-theology wants to retain God as a source of meaning and transcendent value that infuses the entire natural world so that humans and other animals can participate in this spiritual play.

Eco-theology offers a radical critique of both traditional theology and modern technological and economic practices. Wallace (2005: 75) argues that "politically applied deep ecology $\ldots$ is a bearer of green spirituality to a culture that hungers for authentic religion in an age of corporate development and the degradation of our fragile earth community". Eco-theology combines a scientific and naturalist perspective on the environment as a complex eco-system enriched by bio-diversity with a spirituality that values these natural entities and processes beyond their instrumental value for human needs and ends.

There are two problems with this eco-theological approach, despite its significance and importance. First, there is an ambivalence between the location of value in the natural world and the invocation of religious and theological models of 
transcendence, however modified. If something beyond the world is needed to provide value to the world, then that devalues the world, because the world is not all that is the case. Why care about the ultimate value of the earth if the earth is not ultimate? And if the theological aspects of eco-theology are marginalized or de-emphasized, then the problem is that ecotheology as theology becomes instrumental and instills cynicism. Why appeal to religious and spiritual values if a naturalistic and non-religious understanding of the world is sufficient? If it is mainly designed to appeal to religious people because so many humans are Christian, then it necessarily fails as a solution, because religious practitioners are perceptive enough to see through the façade. As radical theologians, we assert that life emerges on what Deleuze $(1988: 122,128)$ calls a plane of immanence, rather than being introduced from elsewhere according to a plan of transcendence.

The other basic problem with many varieties of eco-theology is the appeal to a kind of natural and spiritual harmony. The assumption is that humans existed in a harmonious state of nature up to a certain point, after which transcendence and technology takes over, producing a state of alienation from the natural world. But we know that nature is not in a state of harmony; it does not exist or persist at equilibrium. Humans cannot, even as a part of nature, exist in a perpetual sustainable relationship with their environment. A view of nature that exists in a state of natural harmony is imaginary; it is the product of nostalgia produced by the after-effect of human technology. We romanticize earlier states in light of the conditions of later ones.

This is the reason why many radical eco-philosophers such as Tim Morton have come to oppose the concept of nature itself. In his book Ecology Without Nature, Morton critiques the intrinsically ideological status of the concept of nature, and develops a more critical "dark ecology" (see Morton 2009). In his book Hyperobjects, Morton (2013: 48) argues that global warming is a massive, non-local hyperobject. Hyperobjects bring about the end of modernity, the end of a notion of nature as raw stuff available for humanity to make use of and finally the end of an adequate conception of a closed-off world. Due to the pervasiveness of what Morton calls hyperobjects, there is no container that would allow us to constitute a totally separate object or a separate world. He says that "ecological awareness is a detailed and increasing sense, in science and outside of it, of the innumerable inter-relationships among lifeforms and between life and nonlife" (Morton, 2013: 128).

In a related but slightly different way, Bruno Latour also breaks with the idea of nature. According to Latour, Western modernity names a condition that install a false separation between the realm of human politics and the realm of nature. This split induces a schizophrenic divide between scientists who investigate natural laws and politicians who prescribe laws to human societies. In his book Politics of Nature, Latour (2004: 18-19) states that most of the contemporary discourse on political ecology "merely rehashes the modern Constitution of a two-house politics in which one house is called politics, and the other, under the name of nature, renders the first one powerless". We need to let go of the idea of a separate world of Nature so that we can help fashion a "collective"-that addresses the "progressive composition of the common world" (Latour, 2004: 59). Religion and theology help us constitute a common world together, one that refuses the separation of human culture and politics from the natural world.

In her book Making Peace With the Earth, Vandana Shiva says that peace is only possible if we can eliminate this state of separation of humanity and nature, which affects the separation of humans from humans, women from men and nature from nature. "Separation is at the root of disharmony with nature and violence against it", she writes (Shiva, 2013: 11). Our profound interconnectedness belies this false sense of separation and its concomitant violence. According to Shiva (2013: 13), "making peace with the earth involves a shift from fragmentation and reductionism to interconnectedness and holistic thinking, a shift from violence and exploitation to non-violence and dialogue with the earth". In other words, we need a planetary change from a situation of eco-apartheid to one of interconnectedness. This state of peace that Shiva evokes may seem naive and idealistic, but the fundamental insight is how our separation replicates an ontotheological situation of reality that is cut up into pregiven categories that is false. Overcoming separation involves recognizing and enacting radical change.

Radical change involves positing Earth as subject and thinking from the Earth, as opposed to starting with our anthropomorphic viewpoint and approaching the earth as a static object. In A Thousand Plateaus, Deleuze and Guattari (1987: 39) call for a Geology of Morals, asking, "Who Does the Earth Think It Is?". At the end of their incredible, experimental project, they suggest that earth is the name for an absolute deterritorialization. Territorialization, deterritorialization and reterritorialization are three related concepts that Deleuze and Guattari use, which they borrow from the theorist and architect Paul Virilio. Humans and other animals territorialize space, and they also deterritorialize territory, usually to reterritorialize it. Deleuze and Guattari suggest we think a movement of absolute deterritorialization that cannot be recaptured, recoded or reterritorialized along the same lines.

According to Deleuze and Guattari (1987: 509), "the earth, the glacial, is deterritorialization par excellence: that is why it belongs to the cosmos, and presents itself as the material through which human beings tap cosmic forces". An absolute deterritorialization connects up with a virtual intensive or what they call "smooth" space to generate new forms of becoming. Here is a new way to think about Earth, not as an object of human exploitation, or as a harmonious womb from which we became alienated and need to return, but as an intensive space of theological becoming and change. Deleuze and Guattari claim that when deterritorialization is absolute it "brings about the creation of a new earth". Radical theology is about participating in the creation of a new earth, not destroying or saving the old one.

Radical theology must think change in ecological and planetary terms. Earth no less than God is polluted and rejected, corrupted and abused. Our insights into miscegenation and metamorphosis affirm the divine as well as the worldly in the impure, the polluted, the reject and the flux. Beyond and before the pearly gates is the dirt and dirtiness of material flesh. From dust to dust, and so it is with God, with Earth and with us. And humans emerge out of the humus, the thin layer of topsoil laden with bacteria that makes the earth so fruitful for us even as our deaths contribute to this ongoing process.

After the death-of-God, the question of radical theology remains: What is it that we may learn from that which is beyond, outside or other than ourselves? If radical theology calls into question divine revelation, then it is discernment that is needed. By thinking in ecological and planetary terms, these are contemporary formulations of extremity marked by both a logic of immanence and ultimacy. As such, our thinking is theological even without relying on the category of revelation or supporting supernaturalist claims. And insofar as is based in an ontology of change, we believe it has the capacity to change what it means to think theologically. By our own reading of the lineage and tradition of radical theology, it is our firm belief that the radical theology of and for the future must be postsecular, postliberal, theo-political, onto-theological and ecotheological. This would be a new and different radical theology that 
just might have the capacity to change what it means to think and do theology.

\section{References}

Althaus-Reid M (2004) From Feminist Theology to Indecent Theology. SCM Press: London.

Althaus-Reid M (2006) Liberation Theology and Sexuality. Ashgate Publishing: Burlington, VT.

Asad T (1993) Genealogies of Religion: Discipline and Reasons of Power and Christianity and Islam. The Johns Hopkins University Press: Baltimore, MD.

Berger P (1999) The Desecularization of the World: Resurgent Religion and World Politics. William B. Eerdmans Publishing: Grand Rapids, MI.

Bhandar B and Goldberg-Hiller J (eds) (2015) Introduction In: Plastic Materialities: Politics, Legality, and Metamorphosis in the Work of Catherine Malabou. Duke University Press: Durham, NC.

Brooks D (2003) Kicking the secularist habit: A six-step program. In The Atlantic Monthly March, http://www.theatlantic.com/magazine/archive/2003/03/kick ing-the-secularist-habit/302680/.

Capps WH (1995) Religious Studies: The Making of a Discipline. Fortress Press: Minneapolis, MN.

Caputo JD (2006) Philosophy and Theology. Abingdon Press: Nashville, TN.

Caputo JD (2013) The Insistence of God: A Theology of Perhaps. Indiana University Press: Bloomington, IN.

Casanova J (1994) Public Religions in the Modern World. University of Chicago Press: Chicago, IL.

Crockett C (2011) Radical Political Theology: Religion and Politics After Liberalism. Columbia University Press: New York.

Deleuze G (1988) Spinoza: Practical Philosophy; Hurley R trans. City Lights Books: San Francisco, CA.

Deleuze D and Guattari F (1987) A Thousand Plateaus: Capitalism and Schizophrenia; Massumi B trans University of Minnesota Press: Minneapolis, MN.

Dorrien G (2001) The Making of American Liberal Theology: Imagining Progressive Religion 1805-1900. Westminster John Knox Press: Louisville, KY.

Dorrien G (2006) The Making of American Liberal Theology: Crisis, Irony, and Postmodernity. Westminster John Knox Press: Louisville, KY.

Gill S (1998) Territory In: Taylor MC (ed) Critical Terms for Religious Studies. The University of Chicago Press: Chicago, IL.

Goh I (2014) The Reject: Community, Politics, and Religion after the Subject. Fordham University Press: New York.

Kahn P (2011) Political Theology: Four New Chapters on the Concept of Sovereignty. Columbia University Press: New York.

Latour B (2004) Politics of Nature: How to Bring the Sciences into Democracy; Porter C trans Harvard University Press: Cambridge, MA.

Locke J (1968) A Letter on Toleration; Gough JW trans Clarendon Press: Oxford.

Lovelock J (2009) The Vanishing Face of Gaia: A Final Warning. Perseus Books: New York.

Malabou C (2008) What Should We Do with Our Brain?; Rand S trans Fordham University Press: New York.

Malabou C (2010) Plasticity at the Dusk of Writing: Dialectic, Destruction, Deconstruction; Shread C trans Columbia University Press: New York.

Malabou C (2011a) Changing Difference: The Feminine and the Question of Philosophy; Shread C trans Polity Press: Cambridge, UK.

Malabou C (2011b) The Heidegger Change: On the Fantastic in Philosophy; Skafish P trans SUNY Press: New York.

Manning RR (ed) (2015) Retrieving the Radical Tillich: His Legacy and Contemporary Importance. Palgrave Macmillan: London.
Marsden G (2014) The Twilight of the American Enlightenment: The 1950s and the Crisis of Belief. Basic Books: New York.

Morton T (2009) Ecology without Nature: Rethinking Environmental Aesthetics. Harvard University Press: Cambridge, MA.

Morton T (2013) Hyperobjects: Philosophy and Ecology after the End of the World. University of Minnesota Press: Minneapolis, MN.

Robbins JW (2003) Between Faith and Thought: An Essay on the Ontotheological Condition. University of Virginia Press: Charlottesville, VA.

Robbins JW (2011) Radical Democracy and Political Theology. Columbia University Press: New York.

Rubenstein R (1966) After Auschwitz: Radical Theology and Contemporary Judaism. Macmillan Publishing: New York.

Ruether RR (1970) The Radical Kingdom: The Western Experience of Messianic Hope. Harper and Row: New York.

Schneider ED and Sagan D (2006) Into the Cool: Energy Flow, Thermodynamics, and Life. University of Chicago Press: Chicago, IL.

Shiva V (2013) Making Peace with the Earth. Pluto Press: London.

Smith JZ (1982) Imagining Religion: From Babylon to Jonestown. The University of Chicago Press: Chicago, IL.

Strenski I (2006) Thinking about Religion: An Historical Introduction to Theories of Religion. Blackwell Publishing: Oxford.

TIME Magazine. (1969) A letter from the publisher. 23 December, http://content. time.com/time/magazine/article/0,9171,941765,00.html.

Vahanian G (1957) The Death of God: The Culture of Our Post-Christian Era. George Braziller: New York.

Vattimo G (2007) A prayer for silence: Dialogue with Gianni Vattimo In: Robbins JW (ed) After the Death of God. Columbia University Press: New York.

de Vries H and Sullivan L (eds) (2006) Political Theologies: Public Religions in a Post-Secular World. Fordham University Press: New York.

Wallace MI (2005) Finding God in the Singing River: Christianity, Spirit, Nature. Fortress Press: Minneapolis, MN.

\section{Data availability}

Data sharing not applicable to this article as no datasets were generated or analysed during the current study.

\section{Acknowledgements}

Some of the material for this article is adapted from the conclusion to Jeffrey W Robbins, Radical Theology: A Theological Method for Change, Indiana University Press, forthcoming.

\section{Additional Information}

Competing interests: The authors declare no competing financial interests.

Reprints and permission information is available at http://www.palgrave-journals.com/ pal/authors/rights_and_permissions.html

How to cite this article: Robbins JW and Crockett C (2015). A radical theology for the future: five theses. Palgrave Communications. 1:15028 doi: 10.1057/palcomms.2015.28.

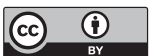

This work is licensed under a Creative Commons Attribution 3.0 International License. The images or other third party material in this article are included in the article's Creative Commons license, unless indicated otherwise in the credit line; if the material is not included under the Creative Commons license, users will need to obtain permission from the license holder to reproduce the material. To view a copy of this license, visit http://creativecommons.org/licenses/by/3.0/ 